DOC.

D101.60/2:

1750

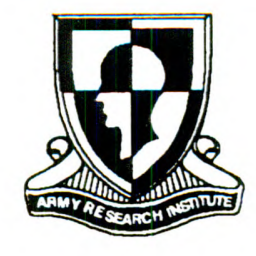

U.S. Army Research Institute

for the Behavioral and Social Sciences

Research Report 1750

\title{
Attrition in the Army from the Signing of the Enlistment Contract through 180 Days of Service
}

\author{
M. A. Fischl \\ U.S. Army Research Institute \\ Deanne L. Blackwell \\ George Washington University \\ Consortium Research Fellows Program
}

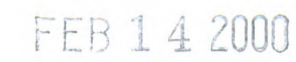

University of Illinois

at Urbana-Champaign

January 2000

Approved for public release; distribution is unlimited. 